\title{
EESTI KEELT EMAKEELENA OMANDAVATE KUUEAASTASTE LASTE SÕNAVARA SEOSED EMADE SÕNAVARAGA
}

\author{
ANDRA KÜTT, REILI ARGUS
}

\begin{abstract}
Annotatsioon. Koolieelikute sõnavara ja seda, kuidas lapse kasvukeskkond sõnavara mõjutab, on eesti keeleteaduses üsna vähe uuritud. Artikli eesmärk on kirjeldada lindistatud argivestluste põhjal kuueaastaste laste sõnavara sõnaliigilist koostist ja vaadata, kuidas see suhestub vanema sõnavara ja selle sõnaliigilise koostisega. Tegemist on eesti keele kontekstis esmase sõnavarauuringuga ühes kindlatele tingimustele vastavas rühmas, kasutuspõhise lähenemise analüüsimaterjaliks on nelja kõrgharidusega ema pooleteisetunnised vestlused lapsega. Tulemused osutavad, et kuueaastaste laste sõnavara ning sõnaliigiline jaotumus ja kindlat sõnaliiki sõnade sagedus on tugevalt seotud vanema kõnega. Nagu vanemate on ka koolieelikute sõnavara adverbi- ja verbikeskne. Kuigi vanemate kõne on mõnevõrra verbikesksem kui lastel, on see siiski sõnade jaotumist sõnaliikidesse ning kindla sõnaliigi sõnade esinemissagedust silmas pidades laste omaga sarnane ja iseloomustab ilmselt argivestlust üldiseltki. Nii vanemate kui ka laste kõnes on väga vähesel hulgal adjektiive, seejuures on lapsele suunatud kõne veel adjektiivivaesem kui lastel. Vanema kõne hulk on ühes pooleteisetunnises lindistuses aga poole suurem kui lapse oma.
\end{abstract}

Võtmesõnad: esimese keele omandamine, sotsiolingvistika, keeleline sisend, sõnaliigiline jaotumine

\section{Sissejuhatus: teoreetiline raamistik}

Kasutuspõhises keeleomandamisteoorias on olulised eelkõige suhtluskeskkond ning lapse ja täiskasvanu suhtlus, mis pakub lapsele keeleliseks arenguks vajaliku (Tomasello 2003: 21-23). Keelelise arengu oluliseks mõjutajaks peetakse lapsele suunatud kõne ehk sisendkeele (ingl 
input $)^{1}$ rolli: ei eeldata pelgalt keeleelementide sobitumist täiskasvanupärasesse struktuuri, vaid nende struktuuride loomist keelestruktuuride statistilise esinemissageduse põhjal ja konkreetse keelekogemuse kaudu (Argus 2008: 11). Michael Tomasello on sõnastanud kasutuspõhise keeleomandamise lähenemise lähtekoha, mille järgi areneb lastel suhtluseesmärkide ja -kavatsuste tajumine osaliselt samadel printsiipidel, mis üldises suhtluses kehtivad (Tomasello 2001a: 155). Seejuures lähtub Tomasello psühholingvistilisest vaatenurgast - grammatika omandamine toimub ainult koondatud tähelepanu situatsioonis (ingl joint attention), kus laps tajub ja täidab suhtluseesmärke ning omandab keelt imiteerimise teel ehk kasutab keelelist sümbolit nii, nagu täiskasvanu teeb samal suhtluseesmärgil lapsele suunatud kõnes (Tomasello 2003: 21-23). Tomasello väitel omandavad lapsed sõnu kultuurilise õppimise kaudu, mida on vastandatud sotsiaalsele õppimisele (Tomasello 1992: 217). Sotsiaalse õppimise puhul lähtub õppeprotsess väljastpoolt - asjad omandatakse teiste käitumise vaatlusega ja välise mõju toimel. Kultuurilise õppimise puhul lähtub õppimine seestpoolt - õppija osaleb koos teistega ühises jagatud tähelepanuga olukorras ja õpib midagi oma vaatepunktist, oma kasvukeskkonnast lähtudes.

Kasutuspõhise keeleomandamisteooria puhul on Tomasello eraldi peatunud kultuurilisel ja bioloogilisel pärandil, mis on keeleomandamise protsessi aluseks. Lapsed saavad informatsiooni nii füüsilisest kui ka sotsiaalsest keskkonnast, kuid toetuvad seejuures mingitele ühiskonna ja kultuuri kindlakskujunenud normidele, väärtustele, teadmistele, kommetele ning saavad teavet alati enda vaatekohast. Tomasello kirjeldab seda piltlikult kui toetumist hiiglase õlgadele, mille järgi laps ei alusta keeleomandamist n-ö täiesti nullist, vaid tema eest on aja jooksul justkui osa tööd tehtud, mingi osa teadmistest on juba välja kujunenud ning laps toetub alati laiemalt ühiskonnas ja kitsamalt kasvukeskkonnas olemasolevatele teadmistele. (Tomasello 2001b: 11-15)

\footnotetext{
Kõige sagedamini kasutatav termin on sisendkõne või -keel (millele vastab ingliskeelses traditsioonis termin input), räägitakse veel lapsele suunatud kõnest (ingl child directed speech, lühendina CDS), mille eestikeelse vastena on kasutatud terminit hoidjakeel. Sisendkõne all käsitletakse igasugust, ka lapse arengule vastavaks kohandamata, aga sellegipoolest lapsele suunatud kõnet (vt nt Argus 2008). Siinses artiklis kasutatakse põhiliselt terminit lapsele suunatud kõne.
} 
Töödesse, mis avavad mõistet 'erinev kasvukeskkond' ja selle seost keelega, on toodud sisse mõiste 'sotsiaalmajanduslik staatus' (ingl socioeconomic status). Sotsiaalmajandusliku staatuse arvestamine keelelise arengu puhul juhindub arvamusest, et areng on kujundatud erinevate kogemuste kaudu ning kõrgema sotsiaalmajandusliku staatusega peredel on paremad ressursid, et tagada lapsele keskkond, mis keelelist arengut toetab (Rowe, Rodgers 1997). On leitud, et kõrgema sotsiaalmajandusliku staatusega vanemate lapsed edestavad madalama sotsiaalmajandusliku staatusega vanemate lapsi mitme keelelise näitaja poolest (sealhulgas näiteks hääldus, lausete pikkus, eri sõnaliikide kasutamine ja kõne hulk), mis mõjutab nii keele omandamist kui ka keelelisi oskusi kooliteed alustades (Glegg, Ginsborg 2006). Mahukad pikiuuringud (vt nt Hart, Risley 1995, 2003) sotsiaalmajandusliku staatuse ja keele seostest näitavad, et erinevus perede vahel on tingitud paljuski sellest, kui palju vanemad oma lastega räägivad, kui suur on teemadering, mille üle arutletakse, kui rikast sõnavara kasutab ema lapsega rääkides ja kui sageli vastab ema lapse küsimustele (Hart, Risley 1995: 181). Marc H. Bornstein (1998) rõhutab, et laste sõnavara kasv on seotud tugevalt ema sõnavaraga ning viisiga, kuidas lapsega rääkida. Lapsele suunatud ema kõne sõnavara suurus ja rikkus, vestluste pikkus ja aeg, mil ema ja laps koos tegutsevad, mõjutavad seega lapse keelt.

Tihti on sotsiaalmajandusliku staatuse mõju hinnatud vaid ühe komponendi kaudu, milleks on kõige sagedamini ema haridus (vt nt Tizard, Hughes 1984; Hart, Risley 1995; McLoyd 1998). Selle näitaja kasuks räägib suhteliselt kerge materjali kogumise viis ja informatsiooni usaldusväärsus. Näiteks kui tavaliselt avaldatakse teavet oma sissetuleku kohta pigem vastumeelselt ning vale informatsiooni andes võib see muuta kogu uurimuse tulemust, siis haridustase märgitakse enamjaolt õige. Samuti, kui sissetulek ja ametialane prestiiž võivad aja jooksul muutuda, siis vanemate haridustase on märksa stabiilsem ning ka vanemate käitumine on palju enam mõjutatud haridustasemest kui sissetulekust või tööalasest prestiižist $^{2}$ (Hoff jt 2012: 593). Pamela Davis Kean (2005) on leidnud, et vanemate haridus määrab suuresti ka nende ootused, mis koduste harivate tegevuste ja mängude kaudu ennustab laste akadeemilist edukust. Mitmed

2 Seejuures on Eesti uurimuses välja toodud ka hariduse ja sissetuleku positiivne seos - akadeemilise kõrgharidusega inimestel on selge palgaeelis teiste tasemete ees (vt nt Leping 2005). 
empiirilised uurimused (vt nt DeGarmo jt 1999; Bornstein jt 2003; Hoffmann 2003) on kinnituseks, et ema haridus on parim üksikindikaator. Haridustaset on seostatud kõige enam ka kõne loomuse ja stiiliga, mis omakorda mõjutab oluliselt lapse sõnavara arengut (Willms 2003). Kuna sotsiaalmajanduslik staatus ja sotsiaalne klass on komplekssed mõisted, mille ühene piiritlemine on raskendatud, on siin kasutatud edaspidi mõistet 'erinev kasvukeskkond'3 (vt ka Kütt 2015), mille avamiseks on vaadeldud haridust ning täpsemalt ühe haridusrühma - kõrgharidusega emade - ja nende laste vahelist suhtlust ja selle seoseid laste keelega.

Keeleüksuste kasutussagedust on nii keele omandamisel kui ka täiskasvanud keelekasutajate puhul peetud oluliseks keele igal tasandil. Sagedusest oleneb näiteks nii käändevormide, muuttüüpide kui ka üksikute lekseemide omandamine (vt nt Vihman, Vija 2006; Argus 2008). Lapsele suunatud kõne pakub hulgaliselt distributiivset infot (vt Redington jt 1998; Behrens 2006) ja laps püüdleb keelt omandades sellise keelevariandi poole, mille vanem talle ette annab. Väidetud on, et sõnaliikide jaotumine lapsele suunatud kõnes muutub lapse kasvades suhteliselt vähe (vt nt Argus, Kõrgesaar 2014) ning et stabiilne sõnaliigiline jaotumine aitab lastel keelestruktuure omandada (Bates, MacWhinney 1987).

Uurides laste varast sõnavara, on leitud, et selles on sageli ülekaalus nimisõnad (nt Fenson jt 1994; Behrens 2006: 16). On arvatud, et nimisõnade ülekaal varase sõnavara hulgas on omane mistahes keele omandamise varasele staadiumile (vt Gentner, Boroditsky 2001; Waxman jt 2013), sest nimisõnade esinemissagedus lapsele suunatud kõnes on suur, või on toodud põhjuseks, et verbid on nimisõnadest kognitiivsemalt või vormimooduslikult keerukamad (Gentner 1982: 301). Samas on leitud, et keeltes, kus lapsele suunatud kõne sisaldab rohkem tegusõnu (nt mandariini keel), on ka lapse varases kõnes enam just tegusõnu (Sandhofer jt 2000). Tegusõnade vähesust on põhjendatud ka eri kultuuridele omaste vestlusstrateegiatega, kus lastel lastakse sageli objekte nimetada (Stoll jt 2012: 316). Seega on andmed nimi-ja tegusõnade esinemissageduse kohta suuresti lahknevad. Teiste sõnaliikide esinemissagedus ei ole uuringute huviväljas olnud.

Eesti keele sõnaliikide jaotumise ja esinemissageduse kohta spontaanses kõnes ei leidu kuigi palju materjali. Sõnavarastatistiliste tööde

3 Juhindutud on arvamusest, et erinev kasvukeskkond tingib ka erineva keelekeskkonna. 
keskmes on olnud näiteks ilukirjandusproosa autorikõne sõnavarastatistika (Kaasik jt 1977), seaduste keele grammatiliste kategooriate sagedus (Viks, Hein 2001) või on esitatud lemmade loend sageduse järjekorras (nt sagedussõnastikes). Andmeid eestikeelsete igapäevavestluste sõnaliigilise jaotumise kohta on samuti vähe, näiteks on uuritud verbide sagedust eesti murrete dialoogides (Uiboaed $\mathrm{jt}^{4}$ ).

Eesti keele sõnaliikide omandamise kohta on MacArthuri-Batesi testi põhiseid uurimusi (nt Schults jt 2012; Urm, Tulviste 2016). Mõnes uurimuses on kombineeritud eri meetodeid, näiteks Ada Urmi töös (2012) on spontaanne kõne üks analüüsi osa. Nii on ka eesti laste kohta leitud, et kui lapse sõnavara koosneb üle 20 sõnast, hakkab suurenema nimisõnade hulk; kui lapse sõnavara on suurem kui 50 sõna, ongi seal ülekaalus nimisõnad, ja alles siis, kui sõnavara veelgi kasvab, suureneb ka tegusõnade hulk (Schults jt 2012: 678). Schultsi jt ning Urmi ja Tulviste uuringute puhul tuleb arvestada, et tegemist on meetodiga, kus vanemad panevad lapse sõnu ise kirja, ja nii võib see anda tulemusi, mis erinevad paljuski spontaanses suhtlussituatsioonis saadutest. Nii näiteks on nimisõnadest raskem registreerida partiklite ja konjunktsioonide kasutust.

Spontaanses suhtlussituatsioonis kasutatud sõnaliikide jaotusest kahe lapse (vanuses 1;3-2;35) ja vanema kõnes võib saada ülevaate Reili Arguse ja Helen Kõrgesaare (2014) artiklist, kus selgus, et eesti lastel on nagu inglise keelt kõnelevatel lastel varase sõnavara hulgas ülekaalus substantiivid. Eesti laste ja lastele suunatud kõnes on sageduselt järgmine sõnaliik verbid, millele järgnevad adverbid ja pronoomenid. Samas ei andnud lastele suunatud keel sellist sõnaliikide jaotumist ette, kuna nimisõnad moodustasid umbes veerandi lapsevanema kõikidest sõnedest. Vaadeldud aasta jooksul nimisõnade esinemissagedus laste keeles vähenes ning vanuses 2;3 sarnanes laste kõne sõnaliikide jaotumine vanemate omaga. (Argus, Kõrgesaar 2014: 40-51). Sellest järeldasid autorid, et vanemad ei kohanda varase sõnavara omandamise perioodil, st enne lapse kolmandat eluaastat, oma keelekasutust kuigi palju.

4 Kristel Uiboaia, Liina Lindströmi ja Kadri Muischneki ettekanne „Frequencies of verbs and verbal constructions across Estonian dialects and standard language“ rahvusvahelises töötoas ,The relative frequencies of nouns, pronouns, and verbs in discourse" Leipzigis 12. augustil 2013.

5 Laste vanust 2;3 tuleks lugeda 2 aastat ja 3 kuud. 
Selle kohta, milline on eestikeelse argivestluse sõnaliigiline jaotumine, praegu andmeid ei ole. Samuti puuduvad andmed selle kohta, milline on vanemate laste, näiteks koolieelikute ja neile suunatud sõnavara ulatus ja jaotumine sõnaliigiti ning kas ja kuivõrd on lapse sõnavara seotud vanema keelega. Puuduvad ka andmed laste sõnavara täpsema koostise kohta, nt selle kohta, mis tüüpi sõnu lastel mingi kindla sõnaliigi sees kõige enam leidub. Seetõttu vaadeldakse siinses kirjutises lähemalt, milline on sõnaliikide jaotumine koolieeliku ja täiskasvanu spontaansetes argivestlustes ning kas vanema kõne sõnavara hulk ja selle sõnaliigiline jaotumine peegeldub lapse kõnes. Seejuures on vaatluse all üks kindlatele tingimustele vastav rühm, kõrgharidusega emad ja nende kuueaastased lapsed, ning üks uurimuse eesmärk on välja selgitada, kas ja kuivõrd erineb sõnavara ühe kindlatele tingimustele vastava rühma sees. Sõnavara sõnaliigilise jaotumise kirjeldamiseks on püstitatud järgmised uurimisküsimused:

1) Kui suur on kuueaastase lapse sõnavara pooleteisetunnise spontaanse argivestluse lindistuses?

2) Kui suur on kuueaastase lapse ema sõnavara pooleteisetunnise spontaanse argivestluse lindistuses?

3) Kui suur on sõnavara ulatuse erinevus vaadeldud laste vahel ja kas see on seotud lapsevanema sõnavara suurusega?

4) Kuidas jaotub vaadeldud laste sõnavara sõnaliikidesse ja mille poolest täpsemalt laste sõnavara erineb?

5) Milliseid seoseid võib luua eri sõnaliikidesse kuuluvate sõnade hulga vahel, nt kas lapsel, kelle sõnavarasse kuulub rohkem verbe, on ka rohkem adverbe, ja lapsel, kelle sõnavarasse kuulub rohkem substantiive, on ka rohkem adjektiive?

6) Millise sõnaliigilise jaotumuse annab ette vanema kõne ning kas ja kuivõrd on see seotud laste kõne sõnaliigilise jaotumusega?

\section{Meetod ja keeleandmestik}

Analüüsi aluseks on spontaanse kõne andmed: kokku 360 minutit igapäevastes situatsioonides lindistatud dialooge, ühtekokku 2132 laste lausungit ning 2757 lapsele suunatud lausungit. Keeleandmestik on kogutud ${ }^{6}$,

${ }^{6}$ Keelematerjali on kogunud ja litereerinud Andra Kütt. Materjal on vormistatud CHILDESi transkribeerimis- ja kodeerimisreeglite kohaselt. 
arvestades kindlat sotsiolingvistilist tegurit, täpsemalt ema haridust. Kõikides peredes kasvab kaks ${ }^{7}$ last ning eesti keel on kodune suhtluskeel. Igalt perelt on analüüsiks lindistatud võrdselt poolteist tundi keelematerjali. Uurimuses osalenud pered on tähistatud koodidega PERE1, PERE2, PERE3, PERE4, lühendatuna P1, P2 jne (vt tabel 1).

Keelematerjali töötlemisel on kasutatud programmi Clan ${ }^{8}$ võimalusi, nt sõnede, lausungite arvu ning lausungi keskmise pikkuse (VKP ${ }^{9}$, ingl MLU ehk Mean Lenght of Utterance) arvutamisel sõnedes ${ }^{10}$, sõnavormide sagedusloendit, kuid põhiosas on andmed töödeldud käsitsi. Sõnaliikide jaotusena on kasutatud eesti grammatikate traditsioonilisemat liigitust nimi-, tegu-, omadus-, määrsõnadeks (st muutumatud sõnad, ka nt ja/ei, ning kaassõnad), arv-, asesõnadeks (ka küsivad ja siduvad asesõnad ning omadussõnalised asesõnad) ja sidesõnadeks. Eraldi kategooria on loodud ülejäänud sõnede jaoks, sinna on liigitatud onomatopoeetilised sõnad, mille sõnaliigiline kuuluvus on sageli ebamäärane, samuti üneemid, hüüdsõnad ja arusaamatud häälikujärjendid. Käsitsi on üle kontrollitud kõik täis- ja osahomonüümid (nt lekseem värvi - kas lekseemi värv omastava või osastava käände või imperatiivi vorm). Analüüsitud on nii laste kui ka laste vestluspartnerite ehk täiskasvanute kõne sõnade jaotumist sõnaliikidesse, sõnavara ulatuse näitamiseks on esitatud ka eri lekseemide hulk (vt tabel 1). Valimi väiksuse tõttu ei kasutata seoste olulisuse määramiseks statistilist analüüsi, kõiki seoseid vaadeldakse igal konkreetsel juhul osakaale ja absoluutarve eraldi kommenteerides.

7 Valimi juures on oluliseks peetud peres kasvavate laste arvu, sest kui lapse juures viibib mitu õde või venda, pälvib iga laps vähem vanema tähelepanu ning ühtlasi kogeb vähem ka ainult temale suunatud kõnet, sest ema kõne hulk jääb muutumatuks hoolimata sellest, kui mitme lapsega suheldakse. Vanema kõnevoorude arv, mis on suunatud konkreetselt vaid ühele lapsele, on kõikide kõnevoorude hulgas samuti väiksem.

8 Programm on loodud CHILDESi andmebaasi tarbeks ning saadaval aadressilt http:// alpha.talkbank.org/clan/ (01.02.2018).

9 Kasutame traditsioonilist lühendit (VKP - väljendi keskmine pikkus).

${ }^{10}$ Sõne on tekstisõna, s.o iga eraldi sõna tekstis (http://www.eki.ee/books/ekk09/ index.php? $\mathrm{p}=6 \& \mathrm{p} 1=2)$. 


\section{Lapse ja lapsele suunatud kõne sõnavara spontaanses argivestluses}

Lapse ja lapsele suunatud kõne andmetest annab ülevaate tabel 1. Laste lausungite hulk ei erine kolme pere puhul oluliselt. Erandiks on PERE3, kus lapsel on lindistuses kõige rohkem lausungeid (658 lausungit), kõige vähem lausungeid on PERE1 lapsel (469 lausungit). Seega esineb PERE1 lapsel pea $29 \%$ vähem lausungeid kui kõige rohkem lausungeid kasutanud lapsel. Keskmiselt kasutavad lapsed pooleteisetunnises vestluses 533 lausungit. Kõige enam lausungeid kasutanud lapse lausungi keskmine pikkus (VKP) on 4,26 sõnet, mis on pisut pikem kui kahel teisel lapsel (pikim VKP on PERE2 lapsel - 4,38 sõnet). Üldiselt jääb laste VKP erinevus aga alla ühe sõne.

Tabel 1. Ülevaade keelematerjalist: lapse ja ema kõne hulk (sõnedes), VKP (sõnedes), lausungite arv ja sõnavara ulatus (lekseemides)

\begin{tabular}{|c|c|c|c|c|c|c|c|c|}
\hline PERE & 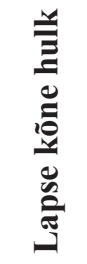 & 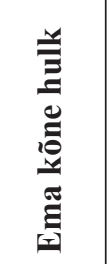 & 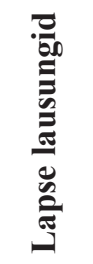 & 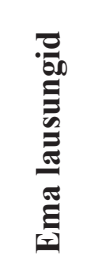 & 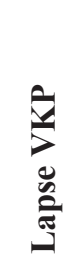 & 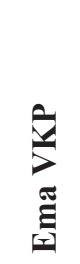 & 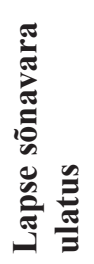 & 总 \\
\hline P1 & 1852 & 4384 & 469 & 683 & 3,85 & 6,07 & 471 & 798 \\
\hline $\mathbf{P 2}$ & 2063 & 4377 & 471 & 715 & 4,38 & 6,11 & 498 & 701 \\
\hline P3 & 2850 & 4699 & 658 & 842 & 4,26 & 5,50 & 415 & 658 \\
\hline P4 & 1934 & 3028 & 534 & 517 & 3,73 & 5,73 & 437 & 557 \\
\hline Keskmine & 2175 & 4122 & 533 & 689 & 4,05 & 5,85 & 455 & 678 \\
\hline Kokku & 8699 & 16488 & 2132 & 2757 & & & & \\
\hline
\end{tabular}

Tabelist on näha, et lindistustes on laste kõne sõnede hulk üsna sarnane, eristub vaid PERE3, kus lapse sõnede hulk on võrreldes teiste lastega märgatavalt suurem. Vestluse lindistussituatsioon ei erinenud kuigi palju teiste perede lindistuste tavapärasest suhtlusolukorrast, kuid erinevalt teistest vestlustest mängis laps koos emaga kujundlikku mõtlemist eeldavat nukumängu, kus välja mõeldud tegelaste vahel oli pidev dialoog. Kitsamalt võiks mängu seostada koondatud tähelepanu ideega (ingl joint activity; joint attention), kus sündmustest rääkides on emal ja lapsel 
ühiseid kogemusi ja need paigutatakse keeleliste vahendite abil ühiselt mõistetavasse raami (Bruner 1981). Seega, kui vanem ja laps on tihedas koondatud tähelepanu situatsioonis, võib see mõjuda ka kõne hulgale. Suhtlus on siis aktiivsem, kui tähelepanu on seotud ühe tegevusega ja vanem suunab lapsele rohkem lausungeid.

Keelelise arengu erinevusi on mitmed uurijad selgitanud muu hulgas mängu iseloomuga, kus mängu valik võib sõnavara kasvu erinevalt mõjutada (nt Bates jt 1979) ${ }^{11}$. Lapse kõne kontekstispetsiifilisuse uurimused (vt nt Bornstein jt 2000; Hoff 2010) viitavad sellele, et hinnates lapse kõnet erinevates situatsioonides, on võimalik saada täielikum pilt lapse kõne arengutasemest ning sõnavarast. Seega võib PERE3 lapse suurem hulk kõnet olla tingitud suhtlemisele ergutavast mängust ning mitmest eri tegevusest, mida ühe lindistuse vältel koos tehti. Kõige väiksem kõne hulk on PERE4 lapsel (1934 sõnet) ja kõige suurem PERE3 lapsel (2850 sõnet), kõne hulga erinevus kõige suurema ja kõige väiksema kõne hulgaga lapse vahel on koguni 32,14\%. Kõikide laste sõnede hulga keskmine on 2174,75 sõnet. See tulemus on üsna sarnane Andra Küti magistritöö andmetega, kus samaealiste laste kõne hulk oli veidike pikemas lindistussituatsioonis (105 minutit) keskmiselt 2032,50 sõnet (Kütt 2015: 32).

Vaadates laste sõnavara ulatust, on näha, et see jääb vahemikku 415 (PERE3) kuni 498 lekseemi (PERE2) ehk kõige rikkama sõnavaraga lapse sõnavara on $20 \%$ mitmekesisem kui kõige väiksema sõnavaraga lapse oma (keskmine näitaja 455,25 lekseemi). Hoolimata sellest, et PERE3 laps oli lindistuse ajal kõige jutukam (kõige rohkem lausungeid ja kõige suurem kõne hulk), jääb laps sõnavara ulatuse poolest teistele alla. Seega ei peegeldu kõne hulgas ilmtingimata sõnavara suurus.

Vaadeldes lapsele suunatud kõnet, on näha, et vanema lausungite hulk erineb palju. Kõige enam lausungeid (842 lausungit) kasutab PERE3 ema ja kõige vähem PERE4 ema (517 lausungit). Lapsele suunatud lausungite arvu vahe on $38 \%$, mis on ühtlasi peaaegu $10 \%$ suurem kui laste lausungite hulga varieeruvus. Keskmiselt esineb lapsele suunatud kõnes 689,25 lausungit ehk 155,75 lausungit enam kui lastel. Seega on lindistatud

${ }^{11}$ Mitmed uurijad on arvanud, et sümboolset tegutsemist ja mõtlemist eeldavad mängud arendavad sõnavara rohkem (vt nt Eriksson jt 2012: 328). Tegevusele suunatud mängude puhul teevad vanemad rohkem keelelisi parandusi kui suhtlemisele suunatud mängude puhul, kus verbaalsed sekkumised on pigem kommentaarid ja küsimused. 
argivestlustes domineerivam pool ema. Otsene seos on lapsele suunatud kõne lausungite ja lapse lausungite hulga vahel - mida rohkem lausungeid on lapsele suunatud, seda rohkem on lindistuses ka lapse enda lausungeid.

Emade kõne hulk erineb kolme pere (PERE1, PERE2, PERE3) puhul üsna vähe, varieerudes 4122 sõnest 4699 sõneni ehk 11\% (vt tabel 1). Laste kõne hulk erineb aga märksa rohkem - kõige suurema ja kõige väiksema kõne hulga vahe on 32\%. Eristub PERE4, kus võrreldes teiste emadega on lapsele suunatud kõnes üle 1000 sõne vähem (3028 sõnet, kusjuures keskmiselt on lapsele suunatud kõnes vanema kohta 4122 sõnet). Kui võrrelda laste ja emade kõne hulka üldiselt, siis selgub, et emade kõne hulk on ligi poole (47\%) suurem kui lastel. Vaadates lapse kõne hulka, on näha seost lapse ja lapsele suunatud kõne vahel - mida rohkem räägib ema, seda suurem on ka lapse enda kõne hulk. Kõige vähem räägib laps, kes kuuleb lindistuse vältel kõige vähem kõnet (PERE4), ning kõige enam kõnet kuulnud laps räägib ka ise kõige rohkem (PERE3).

Lastele suunatud kõne lausungite keskmine pikkus erineb seevastu vähe: kõige väiksem lausungi keskmine pikkus on 5,50 sõnet lausungi kohta (PERE3) ja kõige pikem lausung koosneb 6,11 sõnest (PERE2). Seega jääb ka emade puhul VKP erinevus alla ühe sõne lausungi kohta. Lapsevanema lausungid on aga ühe-kahe sõne võrra pikemad kui lapse omad. Selget seost ema ja lapse lausungite keskmise pikkuse vahel ei ole. Lausungid selle lapse kõnes, kelle ema kasutab kõige pikemaid lausungeid, ei olnud teiste laste lausungitest pikemad.

Ilmneb, et kui laste sõnavara ulatus oli üsna sarnane, on emade sõnavara ulatus aga väga erinev, varieerudes 557 lekseemist 798 lekseemini ning erinevus emade vahel on üle 10\% võrra suurem kui lastel (emadel on sõnavara ulatuse vahe $30 \%$, lastel $20 \%$ ). Ema ja lapse sõnavara ulatus ei ole omavahel selges seoses. Kõige mitmekesisema sõnavaraga ema (PERE1) lapsel on võrreldes kahe teise lapsega (PERE3, PERE4) pisut mitmekesisem sõnavara, kuid see-eest mõnevõrra väiksem kui ligi sada lekseemi vähem kuulnud lapse (PERE2) sõnavara.

Erinevalt lastest on emade kõne hulga ja sõnavara suuruse vahel seos: kõige väiksema kõne hulgaga PERE4 ema kõnes on ka sõnavara ulatus (557 lekseemi) võrreldes teiste emadega väiksem. Põhjuseid võib otsida lindistussituatsioonist. Nimelt oli teiste perede vestlustes ühes lindistussituatsioonis mitu erinevat tegevust, PERE4 lindistuses oli aga üks peamine tegevus - koostati nädalaplaani ja see kestis peaaegu terve 
lindistuse aja. Võib oletada, et lindistuse kontekst mõjutab, kui ühe- või mitmekülgset sõnavara vestluses kasutatakse. Lapse sõnavara ulatus ei peegelda alati lapsele suunatud kõnet, küll on kahele väiksema sõnavara ulatusega lapsele suunatud kõnes võrreldes kahe teise lapsega vähem lekseeme (PERE3, PERE4).

Seega on näha, et ka ühtsel alusel moodustatud rühma sees leidub nii laste kui ka emade kõnes erinevusi. Erinevused on nii vanema kõne hulgas kui ka osaliselt sõnavara ulatuses ning mida rohkem vanem räägib ja kõnevoore lapsele suunab, seda suurem on ka lapse enda kõne hulk. Kõige vähem peegeldub vanema kõne lapse lausungi keskmises pikkuses. Erinevuste üks põhjus võib olla lindistussituatsiooni ehk täpsemalt lindistuse ajal tehtavate tegevuste erinevus.

\section{Laste kõne jaotumine sõnaliikidesse}

Tabel 2 annab ülevaate laste kõne sõnede ja lekseemide jaotumisest sõnaliikidesse. Vaadates sõnavara jaotumist, on näha, et laste kõnes on kõige sagedasemad adverbid ja verbid. Seega erineb tulemus oluliselt sellest, mis on saadud väiksemate laste kõne sõnaliigilise jaotuse kohta. Kui alla kolmeaastaste laste kõnes on kõige enam substantiive (Argus, Kõrgesaar 2014: 51), siis kuueaastaste laste puhul on sagedasemad verbid ja adverbid. Schultsi jt (2012: 678) andmetel on eesti väikelaste (vanuses 0;8-1;4) varase sõnavara hulgas vähe adverbe. Kuna siinses analüüsis kasutatud materjal pärineb vanemate laste kõnest, siis võib oletada, et adverbide suur hulk vaatlusaluste laste kõnes võib tuleneda vanusest, aga ka andmekogumise metoodilistest erinevustest: Schultsi jt materjal on kogutud ema täidetava päevikuga, väikelaste kommunikatiivseid oskusi mõõtva MacArthuri suhtlemise arengu testiga (ingl MacArthur Communicative Developmental Inventories, lühend CDI) ning võib oletada, et lapse kasutatud adverbe ei ole vanemal ilmselt kuigi kerge tähele panna ja üles kirjutada.

Adverbide hulk on laste kõnes siiski väga erinev, ulatudes 473 sõnest (PERE2) 736 sõneni (PERE3), suurima ja väikseima kasutushulga vahe on seega 36\% (keskmine näitaja 530,25 sõnet). Päris otseselt ei ole seotud adverbisõnede koguhulk ja osakaal. Näiteks on PERE1 lapsel lastevahelises võrdluses adverbide (518 sõnet) suurim osakaal (28\%), aga kõige rohkem adverbe kasutanud lapse kõnes (PERE3 - 736 sõnet) on adverbide osakaal veidi väiksem $-26 \%$. 
Tabel 2. Sõnaliikide jaotumine laste kõnes (sõned/lekseemid)

\begin{tabular}{|c|c|c|c|c|c|c|c|c|c|}
\hline PERE & 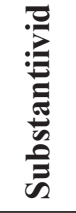 & $\frac{7}{2}$ & 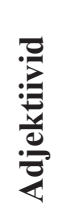 & $\frac{}{\frac{7}{0}}$ & 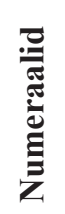 & 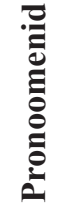 & 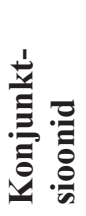 & $\Xi$ & $\frac{\vec{a}}{\underline{y}}$ \\
\hline P1 & $\begin{array}{c}319 / \\
183\end{array}$ & $\begin{array}{c}401 / \\
93\end{array}$ & $\begin{array}{l}56 / \\
32\end{array}$ & $\begin{array}{c}518 / \\
94\end{array}$ & $\begin{array}{c}63 / \\
6\end{array}$ & $\begin{array}{c}315 / \\
24\end{array}$ & $\begin{array}{c}96 / \\
7\end{array}$ & $\begin{array}{l}84 / \\
32\end{array}$ & $\begin{array}{c}1852 / \\
471\end{array}$ \\
\hline P2 & $\begin{array}{c}356 / \\
179 \\
\end{array}$ & $\begin{array}{c}487 / \\
89 \\
\end{array}$ & $\begin{array}{c}112 / \\
48\end{array}$ & $\begin{array}{c}473 / \\
100 \\
\end{array}$ & $\begin{array}{c}23 / \\
10 \\
\end{array}$ & $\begin{array}{c}389 / \\
29\end{array}$ & $\begin{array}{c}110 / \\
7\end{array}$ & $\begin{array}{c}113 / \\
36\end{array}$ & $\begin{array}{c}2063 / \\
498\end{array}$ \\
\hline P3 & $\begin{array}{c}343 / \\
122\end{array}$ & $\begin{array}{c}686 / \\
88\end{array}$ & $\begin{array}{c}107 / \\
36\end{array}$ & $\begin{array}{c}736 / \\
86\end{array}$ & $\begin{array}{c}112 / \\
9\end{array}$ & $\begin{array}{c}522 / \\
36\end{array}$ & $\begin{array}{c}237 / \\
7\end{array}$ & $\begin{array}{c}107 / \\
31\end{array}$ & $\begin{array}{c}2850 / \\
415\end{array}$ \\
\hline P4 & $\begin{array}{c}367 / \\
168 \\
\end{array}$ & $\begin{array}{c}427 / \\
66 \\
\end{array}$ & $\begin{array}{l}51 / \\
26\end{array}$ & $\begin{array}{c}394 / \\
71 \\
\end{array}$ & $\begin{array}{c}91 / \\
12 \\
\end{array}$ & $\begin{array}{c}302 / \\
24\end{array}$ & $\begin{array}{c}98 / \\
10 \\
\end{array}$ & $\begin{array}{c}204 / \\
60 \\
\end{array}$ & $\begin{array}{c}1934 / \\
437\end{array}$ \\
\hline Keskmine & $\begin{array}{c}346 / \\
163\end{array}$ & $\begin{array}{c}500 / \\
84\end{array}$ & $\begin{array}{c}81 / \\
35\end{array}$ & $\begin{array}{c}530 / \\
88\end{array}$ & $\begin{array}{c}72 / \\
9\end{array}$ & $\begin{array}{c}382 / \\
28\end{array}$ & $\begin{array}{c}135 / \\
8\end{array}$ & $\begin{array}{c}127 / \\
39\end{array}$ & \\
\hline
\end{tabular}

Laste kasutatud adverbide hulgas moodustavad kõige suurema rühma muutumatud sõnad ei/ja ja keelavad partiklid ära/ärge. Tegemist on üksustega, mis on mõnel juhul verbivormi, mõnel teisel juhul aga vastuse koosseisus, seega ühelt poolt on need grammatilise vormi osad, teiselt poolt leksikaalsed üksused. Kuna aga esinemisjuhtude ehk sõnede hulga arvutamisel lähtuti tekstisõnadest ehk sõnaliik määrati iga sõne puhul eraldi, kasvatavadki sagedasti esinenud muutumatud sõnad (nt $e i$ ) adverbide hulka. Vestlustes esineb palju deiktilisi koha-asemäärsõnu (näiteks sinna, seal, sealt, siia, siin), mis iseloomustavad hästi ka kodust argisuhtlust üldiselt. Sage on ka rõhumäärsõna $k a$, samuti ajamäärsõna nüüd kasutus.

Kasutussageduselt teine sõnaliik on verbid. Verbisõnede hulk varieerub vestluses lasteti veelgi enam - 401 sõnest (PERE1) 686 sõneni (PERE3) ning kahe kasutushulga vahe on $41 \%$. Erinevalt adverbidest on verbisõnede hulgal otsene seos ka sõnaliigi osakaaluga kõikide sõnaliikide sõnedes. Laste võrdluses kõige enam verbe kasutanud lapse (PERE3) kõnes on verbide koguhulk ka võrdluses teiste lastega kõige suurem (24\%) ning kõige vähem verbe kasutanud lapse (PERE1) kõnes on verbide osakaal kõikides sõnedes kõige väiksem (22\%). Samamoodi nagu Arguse ja Kõrgesaare uurimusest on näha (2014: 41), torkab ka vanemate laste kõne 
sõnaliigilise jaotuse puhul silma see, et kui laps kasutab rohkem verbe, kasutab ta ka rohkem adverbe. Näiteks esineb kõige enam verbe kasutanud lapsel (PERE1) ka kõige rohkem adverbe.

Laste kõnes on substantiive ja pronoomeneid pea ühesuguse sagedusega. Substantiivide hulk (pooleteisetunnises kõnes keskmiselt 346 substantiivi) varieerub laste kõnes aga pronoomenite hulgast tunduvalt vähem: 319 sõnest (PERE1) 367 sõneni (PERE4). Erinevus kõige vähem ja kõige enam substantiive kasutanud lapse vahel on 13\%. Pronoomenite hulk (pooleteisetunnises kõnes keskmiselt 382 pronoomenit) varieerub 302 sõnest (PERE4) 522 sõneni (PERE3), kahe kasutushulga vahe on koguni 42\%. Seega kasutavad lapsed vestluses keskmiselt üsna võrdselt nii substantiive kui ka pronoomeneid, kuid varieeruvus on suurem siiski pronoomenite kasutuses. Ühtviisi palju kasutavad lapsed pronoomenit $\mathrm{ma}$ / mina (kõige enam pronoomeneid kasutanud PERE3 laps aga kõige rohkem, 147 korral). Vaadates, kui suure hulga moodustab mõlema sõnaliigi hulk laste kõne hulgast, on näha, et pronoomenite osakaal on mõnevõrra suurem. Pronoomenite osakaal varieerub 16\%-st (PERE4) 19\%-ni (PERE2), substantiivide osakaal 12\%-st (PERE3) 19\%-ni (PERE4).

Tulemus adjektiivide vähese kasutuse kohta on sarnane nii Arguse ja Kõrgesaare tulemustega (Argus, Kõrgesaar 2014) kui ka inglise keelt omandavate nooremate laste kohta tehtud uurimustega (Li, Fang 2011), kus on muuhulgas samuti leitud, et lapsed kasutavad märksa sagedamini adverbe kui adjektiive. Adjektiivide hulk varieerub 51 sõnest (PERE4) 112 sõneni (PERE2) (vahe 54\%), keskmiselt olid lapsed pooleteise tunni jooksul kasutanud adjektiive vaid 81 korral. Adjektiividest vähem esineb laste kõnes veel vaid numeraale (keskmiselt 72 sõnet). Seejuures on adjektiivide kasutussageduse varieeruvus suur. Kui kahe lapse lindistuses esineb adjektiive üle saja korra (PERE2, PERE3), siis kaks teist last (PERE1, PERE2) kasutavad vestluses adjektiive üle poole vähem.

Konjunktsioone (541 sõnet) ja numeraale (289 sõnet) esineb laste kõnes samuti vähe: keskmiselt 135 konjunktsiooni ja 72 numeraali. Ka osakaal jääb nende sõnaliikide puhul üldiselt väikseks. Konjunktsioonide osakaal jääb vahemikku 1\% (PERE2) - 2\% (PERE4), numeraalide osakaal 1\% (PERE2) - 5\% (PERE4). 127 sõne puhul on tegemist kas ebamäärase sõnaliigilise kuuluvusega sõna või hüüdsõnade ja üneemidega ${ }^{12}$. Joonis 1 annab ülevaate laste kõne sõnaliigilisest jaotumisest.

\footnotetext{
12 Joonistel esitatud rühmas „Muu“.
} 


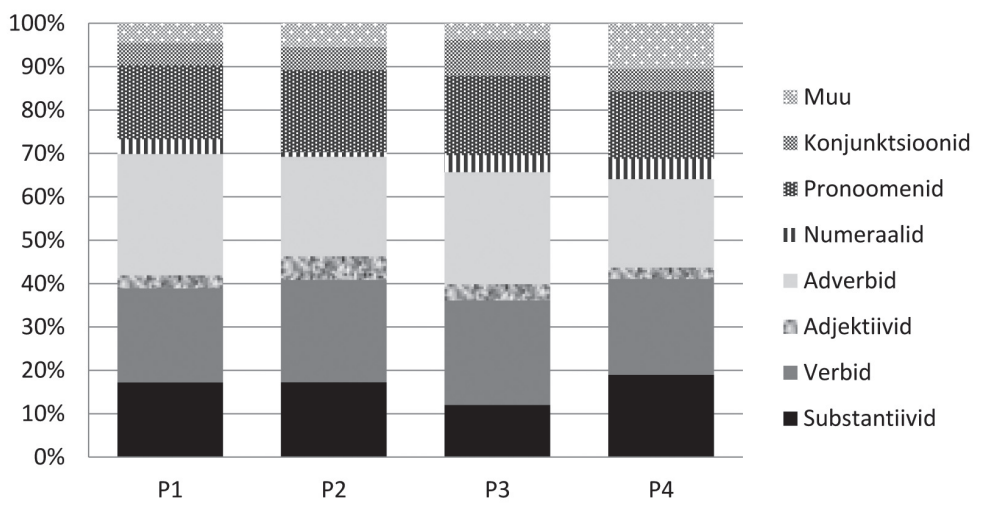

Joonis 1. Laste kõne jaotumine sõnaliikidesse (sõnedes)

Jooniselt 1 on näha, et koolieelikute spontaanses argivestluses on kõige rohkem adverbe ja verbe, üsna võrdne hulk substantiive ja pronoomeneid, viimaste hulga varieeruvus on seejuures suurem kui substantiividel. Adjektiivide hulk jääb laste kõnes aga väiksemaks kui näiteks konjunktsioonide, ebamäärase sõnaliigilise kuuluvusega sõnade ning numeraalide hulk.

Kui vaadata laste sõnavara lekseemide arvu sõnaliigiti, saab ülevaate, kui rikas või kui piiratud on mingi kindla sõnaliigi sõnavara (vt joonis 2).

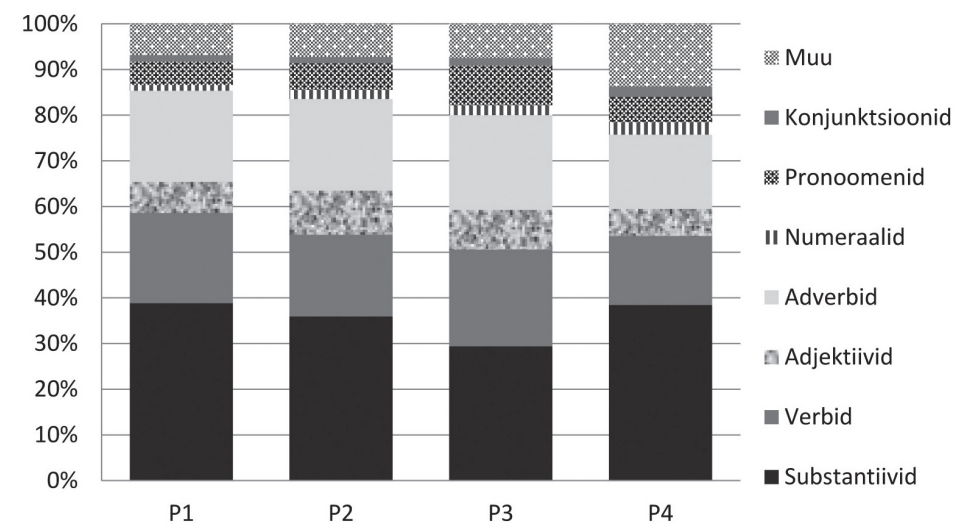

Joonis 2. Laste sõnavara jaotumine sõnaliikidesse (lekseemides)

Kõige rikkam sõnavara on kõikidel lastel substantiivide puhul, keskmiselt esines lindistuses 163 substantiivilekseemi, substantiivide osakaal 
varieerub 29\%-st (PERE3) 39\%-ni (PERE1). Esineb seos substantiivi- ja verbisõnavara ulatuse vahel - mida rohkem on lapsel substantiivilekseeme, seda enam esineb kõnes ka verbilekseeme.

Küllaltki mitmekesine ja seejuures võrdselt rikas on adverbi- ja verbisõnavara, keskmiselt on laste kõnes 84 verbi ja 88 adverbi. Adjektiivide mitmekesisus on kuigivõrd suurem kui pronoomenite, konjunktsioonide või ebamäärase sõnaliigilise kuuluvusega sõnade oma, kuid jääb ka lekseemiti üsna väikseks (vestlustes keskmiselt 35 lekseemi).

\section{Sõnaliikide jaotumine lapsele suunatud kõnes ja selle seosed lapse kõnega}

Vaadates lastele suunatud kõnet, saab näha, millise sõnaliikide jaotumise annab see lastele ette ning kas ja kuivõrd on lapse ja ema kõne sõnaliigiline jaotumine seotud. Tabel 3 annab ülevaate sõnaliikide jaotumisest lastele suunatud kõnes.

Tabel 3. Sõnaliikide jaotumine emade kõnes (sõned/lekseemid)

\begin{tabular}{|c|c|c|c|c|c|c|c|c|c|}
\hline PERE & 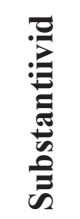 & & & 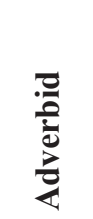 & 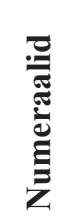 & 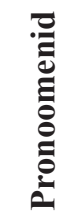 & 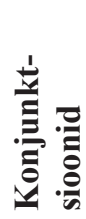 & $\stackrel{\Xi}{\Sigma}$ & $\begin{array}{l}\frac{z}{y} \\
\frac{y}{\theta}\end{array}$ \\
\hline P1 & $\begin{array}{l}727 / \\
335\end{array}$ & $\begin{array}{c}991 / \\
151\end{array}$ & $\begin{array}{c}166 / \\
73\end{array}$ & $\begin{array}{c}872 / \\
143 \\
\end{array}$ & $\begin{array}{c}695 / \\
15 \\
\end{array}$ & $\begin{array}{c}323 / \\
34\end{array}$ & $\begin{array}{c}323 / \\
9 \\
\end{array}$ & $\begin{array}{c}287 / \\
38 \\
\end{array}$ & $\begin{array}{c}4384 / \\
798\end{array}$ \\
\hline P2 & $\begin{array}{l}702 / \\
281\end{array}$ & $\begin{array}{c}1187 / \\
137\end{array}$ & $\begin{array}{c}227 / \\
80\end{array}$ & $\begin{array}{c}1062 / \\
125\end{array}$ & $\begin{array}{c}30 / \\
9\end{array}$ & $\begin{array}{c}817 / \\
37\end{array}$ & $\begin{array}{c}228 / \\
7\end{array}$ & $\begin{array}{c}124 / \\
25\end{array}$ & $\begin{array}{c}4377 / \\
701\end{array}$ \\
\hline P3 & $\begin{array}{l}619 / \\
229\end{array}$ & $\begin{array}{c}1191 / \\
129\end{array}$ & $\begin{array}{c}182 / \\
61\end{array}$ & $\begin{array}{c}1151 / \\
136\end{array}$ & $\begin{array}{c}144 / \\
12\end{array}$ & $\begin{array}{c}824 / \\
37\end{array}$ & $\begin{array}{c}359 / \\
13\end{array}$ & $\begin{array}{c}229 / \\
41\end{array}$ & $\begin{array}{c}4699 / \\
658\end{array}$ \\
\hline P4 & $\begin{array}{l}481 / \\
200\end{array}$ & $\begin{array}{c}856 / \\
104\end{array}$ & $\begin{array}{l}87 / \\
47\end{array}$ & $\begin{array}{c}703 / \\
116\end{array}$ & $\begin{array}{c}37 / \\
14\end{array}$ & $\begin{array}{c}591 / \\
34\end{array}$ & $\begin{array}{c}141 / \\
7\end{array}$ & $\begin{array}{c}132 / \\
35\end{array}$ & $\begin{array}{c}3028 / \\
557\end{array}$ \\
\hline Keskmine & $\begin{array}{l}632 / \\
261\end{array}$ & $\begin{array}{c}1056 / \\
130\end{array}$ & $\begin{array}{c}165 / \\
65\end{array}$ & $\begin{array}{c}947 / \\
130\end{array}$ & $\begin{array}{c}226 / \\
12\end{array}$ & $\begin{array}{c}639 / \\
35\end{array}$ & $\begin{array}{c}263 / \\
9\end{array}$ & $\begin{array}{c}193 / \\
35\end{array}$ & \\
\hline
\end{tabular}

Lastele suunatud kõne on verbikeskne. Kui laste kõnes esineb kõige enam adverbe ja seejärel verbe, siis vanema kõnes on kaks kõige suuremat sõnaliigirühma samad, kuid rohkem esineb verbe. Nagu laste puhul on 
verbide hulga varieeruvus suur ka emade puhul. Kõige enam verbe esineb PERE2 emal (1187) ja kõige vähem PERE4 emal (856 sõnet), vahe on seega ligi $28 \%$, mis on siiski väiksem kui lastel. Lasteti on verbikasutuse varieeruvus ka kõikide sõnaliikide võrdluses kõige suurem (41\%). Kui võrrelda aga verbisõnede koguhulka, on näha, et vanema kõnes on ühes vestluses peaaegu poole rohkem verbe kui lastel. Lastele suunatud kõnes on keskmiselt 1056 verbi, laste kõnes keskmiselt 500 verbi. Vanema kõnes esinevate verbide hulk on otseselt seotud lapse kõnega - mida verbikesksem on vanema kõne, seda enam verbe esineb ka lapse kõnes, ja mida vähem verbe vanem kasutab, seda vähem on neid ka laste kõnes.

Ühtlasi on lastele suunatud kõnes suur adverbide kasutussagedus. Ühes vestluses esineb keskmiselt 947 adverbisõnet. Ka adverbide hulga varieeruvus on suur, ulatudes 703 sõnest (PERE4) 1151 sõneni (PERE3). Kõige enam ja kõige vähem adverbe kasutanud ema adverbikasutuse vahe on $39 \%$, mis on laste adverbikasutusega väga sarnane ehk vaid $3 \%$ suurem. Nagu verbe on ka adverbe emade kõnes peaaegu poole rohkem kui laste kõnes. Keskmiselt on lastele suunatud kõnes 947 adverbisõnet, laste kõnes 530 adverbisõnet. Nii nagu vanema kõne verbikesksus mõjutab laste kõnet, mõjutab seda ka vanema adverbide hulk. Kõige enam verbe kasutanud vanema laps kasutab lindistuses samuti kõige rohkem adverbe ja vastupidi.

Nagu laste kõnes on ka vanemate kõnes pronoomenid ja substantiivid pea ühesuguse sagedusega. Kui laste kõnes esineb enam substantiive, siis lastele suunatud kõnes on pronoomeneid mõni sõne rohkem. Ka vanemate kõnes varieerub pronoomenite hulk veelgi enam kui substantiivide puhul. Kui koguhulgana esineb lastele suunatud kõnes pronoomeneid keskmiselt peaaegu sama palju kui substantiive, vaid 7 sõnet enam (639 pronoomenit), siis pronoomenite kasutus on vanemate puhul väga erinev. Kõige vähem pronoomeneid kasutab PERE1 ema (323 sõnet), kõige enam PERE3 ema (824 sõnet), seega on kahe kasutussageduse vahe 61\%. Lasteti on varieeruvus samuti suur $-42 \%$. Kui lapsed kasutavad sagedamini pronoomenit ma/mina, siis vanema kõnes esineb palju teisele isikule viitavat asesõna (sa/sina) ning pronoomenit see, kuid samamoodi nagu kõige enam pronoomeneid kasutanud PERE3 laps kasutab ka tema ema kõige sagedamini pronoomenit ma/mina. Vanema ja lapse kõne hulga vahel esineb jällegi seos - mida enam pronoomeneid on vanema kõnes, seda enam on neid ka lapse kõnes. Seejuures on ka kasutushulgana vanema ja lapse vahel 
ka seosed pronoomenilekseemide vahel - vanema sagedasti kasutatud pronoomen esineb sagedasti ka lapse kõnes.

Substantiivide hulk (keskmiselt esineb pooleteisetunnises kõnes 632 substantiivi) varieerub 481 sõnest (PERE4) 727 sõneni (PERE1), vahe on kogunisti 34\%. Seega on lastele suunatud kõnes substantiivide kasutus palju varieeruvam kui lastel, kus erinevus kõige vähem ja kõige enam substantiive kasutanud lapse vahel on $13 \%$. Nii nagu verbide, adverbide ja pronoomenite puhul, on ühes lindistuses lastele suunatud keskmine substantiivide hulk peaaegu kaks korda suurem kui lastel. Erinevusena ei ole lastele suunatud kõnes esinevate substantiivide hulk seotud lapse kõnega. Kõige enam substantiive kasutanud ema (PERE1) laps on võrreldes teiste lastega kasutanud substantiive hoopis kõige vähem.

Kui laste kõnes esineb adjektiive vähe (keskmiselt 81 sõnet), siis vanema kõnes on adjektiive teiste sõnaliikidega võrdluses kõige vähem. Keskmiselt on ühes lindistuses vaid 165 adjektiivi. Seda on vähem kui konjunktsioone, numeraale ja ebamäärase sõnaliigilise kuuluvusega sõnu, mida on vanemate kõnes keskmiselt vastavalt 263, 226 ja 193 sõnet. Seejuures varieerub adjektiivide hulk vanema kõnes palju - kõige enam adjektiive kasutab PERE2 ema (227 sõnet) ja kõige vähem PERE4 ema (87 sõnet). Adjektiivide sageduse vahe on seega enam kui kahekordne (62\%). Isegi vähese adjektiivide kasutuse korral on vanema ja lapse kõne vahel jälle selge seos - mida rohkem adjektiive kasutab vanem, seda rohkem teeb seda ka laps.

Joonis 3 annab ülevaate emade kõne sõnaliigilisest jaotumisest.

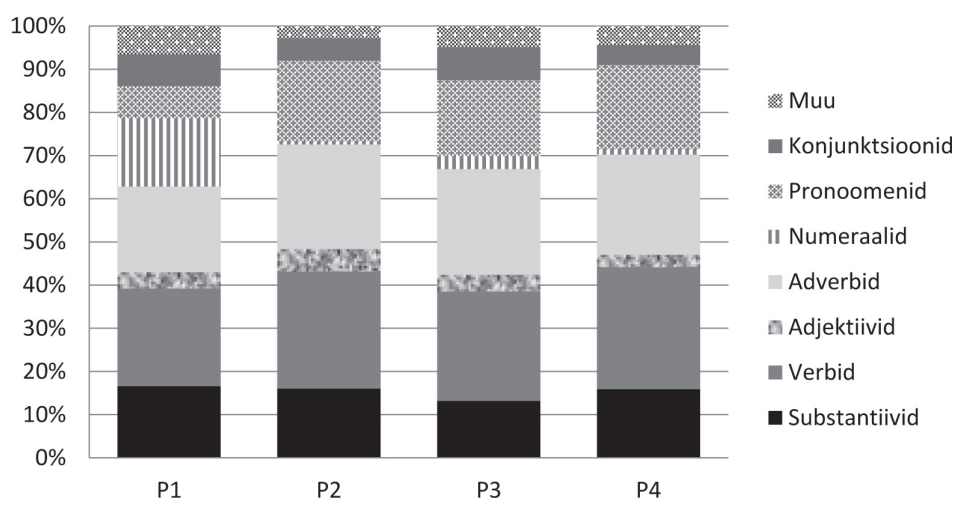

Joonis 3. Emade kõne jaotumine sõnaliikidesse (sõnedes) 
Kõige suurema osa moodustavad ka lastele suunatud kõnes verbid ja adverbid, seega on vanema kõne pisut enam verbikeskne kui lastel, kes kasutasid rohkem adverbe. Nagu laste kõnes on ka vanema kõnes pronoomeneid ja substantiive peaaegu võrdne kogus. Suure erinevusena tuli esile adjektiivivaene lastele suunatud kõne. Kui laste kõnes oli adjektiive vähe, siis lastele suunatud kõnes esines neid kõikide sõnaliikidega võrreldes kõige vähem.

Kui võrrelda aga sõnaliigiti vanemate ja laste kõne hulka, on näha, et pea kõikide sõnaliikide puhul on lastele suunatud kõne hulk ligi poole suurem kui lastel endil. Vanema kõne annab lapsele väga tugevalt ette sõnaliigilise jaotumuse verbide, adverbide, pronoomenite, adjektiivide, konjunktsioonide, numeraalide ja muude sõnade puhul - mida rohkem on vanema kõnes kindla sõnaliigi sõnesid, seda enam on neid ka lapse kõnes. Erand on substantiivid, mille puhul vanema suurem kõnehulk ei ole mõjutanud lapse substantiivide hulka.

Joonis 4 annab ülevaate, kui ulatuslik on vanema kõnes mingi kindla sõnaliigi sõnavara.

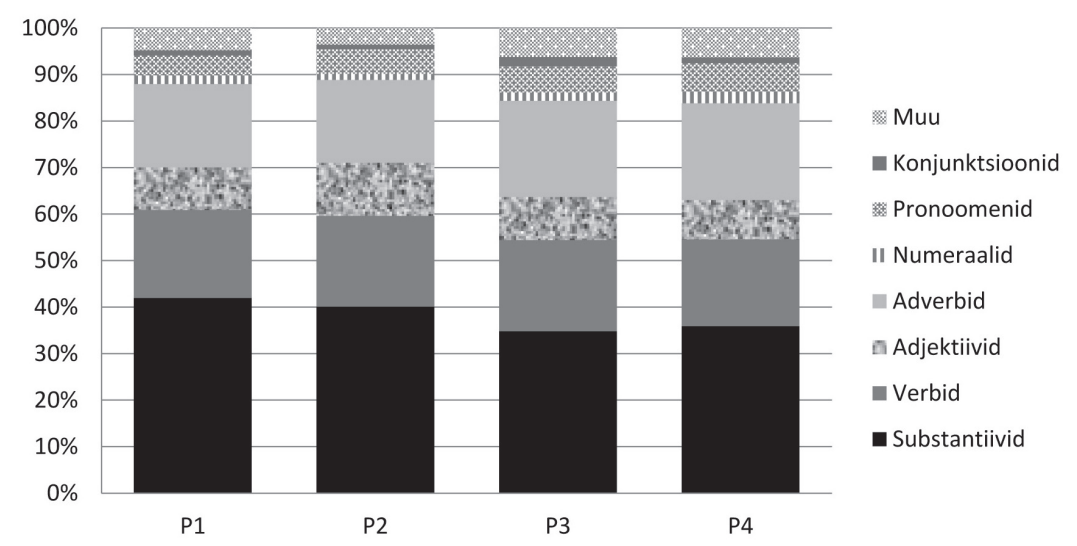

Joonis 4. Emade sõnavara jaotumine sõnaliikidesse (lekseemides)

Kõige rikkam on ka vanemate sõnavara substantiivide poolest, keskmiselt esineb emade lindistuses 261 substantiivilekseemi. Laste kõnes esineb umbes sada substantiivilekseemi vähem kui emade kõnes, kuid võrreldes laste ja vanemate kõne hulka, võib öelda, et laste substantiivisõnavara on mõnevõrra tihedam vanemate substantiivisõnavarast (vanemad kasutavad 
üht lekseemi keskmiselt 2,4 korda, lapsed 2,1 korda). Võrdselt rikas on emade verbi-ja adverbisõnavara: keskmiselt esineb vestluses 130 verbi-ja adverbilekseemi. Ka lastel on nende kahe sõnaliigi sõnavara ulatus peaaegu võrdne. Kõrvutades jälle kõne hulka ja eri lekseeme, on näha, et vestluses on laste adverbi- ja verbisõnavara vanemate omast ulatuslikum, sest erinevaid lekseemid moodustavad vastava sõnaliigi koguhulgast suurema osakaalu kui emade kõnes. Kuigi adjektiive esineb vanemate kõnes vähem kui konjunktsioone, numeraale ja ebamäärase sõnaliigilise kuuluvusega sõnu, on adjektiivide sõnavara nendest sõnaliikidest mitmekesisem. Keskmiselt kasutavad vanemad vestluses 65 adjektiivilekseemi. See on suurem arv kui lastel, kuid kuna vanemate adjektiivide hulk (sõnedes) on lastest üle poole suurem, tuleb välja, et ka adjektiivide sõnavara on just lastel tihedam kui emadel. Teiste sõnaliikide puhul (pronoomenid, konjunktsioonid, numeraalid ja muud sõnad) esineb sama seaduspärasus: võrreldes sõnaliikide kõne hulka, on laste vastava sõnaliigi sõnavara tihedam. Analüüsides lapsele suunatud kõne sõnavara mitmekesisust ühe sõnaliigi sees, tuleb esile, et substantiivide puhul on kõige rikkama sõnavaraga ema (PERE1) lapsel ka laste hulgas kõige ulatuslikum substantiivisõnavara. Vestluses kõige piiratuma substantiivisõnavaraga ema (PERE4) lapsel on lastest kõige piiratum substantiivisõnavara. Verbide puhul on seos samuti otsene - mida rohkem eri lekseeme kasutab ema, seda enam on neid ka lapsel. Ka adverbide puhul on näha ema sõnavara mõju: kõige enam adverbilekseeme kasutanud ema (PERE3) lapsel on samuti kõige mitmekesisem adverbisõnavara; kõige vähem adverbilekseeme kasutanud ema (PERE4) lapsel aga kõige piiratum adverbisõnavara. Lapsele suunatud kõne sõnavara rikkus avaldub positiivse seosena ka adjektiivide, pronoomenite, konjunktsioonide puhul.

Vanema ja lapse kõnes esinevad suuremad sõnaliigid peaaegu samas järjestuses, erandiks on adjektiivid, mida vanema kõnes on kõige vähem. Peaaegu kõikide sõnaliikide (v.a substantiivide) sõnade hulk on otseselt seotud lapse kõnega - mida rohkem on vanema kõnes mingi sõnaliigi sõnu, seda enam esineb neid ka lapse kõnes ja vastupidi. 


\section{Kokkuvõte}

Ühtsetel alusel moodustatud rühma sees leidub nii laste kui ka emade kõnes erinevusi ning võib öelda, et lapsele suunatud keel mõjutab otse lapse keelt: mida rohkem ema räägib ja kõnevoore lapsele suunab, seda suurem on ka lapse enda kõne hulk. Keskmiselt esineb lapsele suunatud kõnes 689,25 lausungit ehk 155,75 lausungit enam kui lastel, mis näitab, et lindistatud argivestlustes on domineerivam pool ema. Emade kõne hulk on seejuures ligi poole (47\%) suurem kui lastel. Nelja kõrgharitud ema pere argivestluste esmase analüüsi põhjal võib öelda, et kuueaastaste eesti laste pooleteisetunnise lindistuse sõnavara koosneb 415-498 lekseemist, lastega vestlevate emade sõnavaras on samal ajal aga 557-798 lekseemi. Sõnavara ulatuse erinevus laste vahel on $20 \%$ ning emade vahel $30 \%$. Vaadeldud materjali põhjal ei saa väita, et kõige suurema sõnavaraga ema lapsel oleks samuti kõige suurem sõnavara ja vastupidi.

Võib öelda, et erinevalt varasematest eesti sõnavaraliigilise jaotumuse kohta saadud uurimustest nooremate laste kohta ei ole kuueaastaste laste sõnavara mitte nimisõna-, vaid pigem adverbi- ja verbikeskne. Nii vanemate kui ka laste kõnes on kaks kõige suuremat sõnarühma adverbid ja verbid, lastele suunatud kõne on küll mõnevõrra enam verbikesksem. Nagu laste on ka emade kõnes pea ühesuguse sagedusega pronoomeneid ja substantiive. Pronoomenite osakaal on laste kõnes mõnevõrra suurem ning varieeruvam. Kui lasteti on substantiivide kasutus üsna ühtlane, siis vanemate kõnes on see palju muutlikum: substantiivide hulk varieerub lastel $13 \%$ ja vanematel $34 \%$. Adjektiivide kasutus on nii lastele suunatud kõnes kui ka laste kõnes väga väike. Emade kõnes on seejuures adjektiive teiste sõnaliikidega võrreldes vähem kui konjunktsioone, numeraale ja ebamäärase sõnaliigilise kuuluvusega sõnu. Isegi vähese adjektiivide kasutuse korral on ema ja lapse kõne vahel jälle selge seos - mida rohkem adjektiive kasutab vanem, seda enam teeb seda ka laps.

Eri sõnaliikidesse kuuluvate sõnede hulga puhul on laste vahel mõningaid erinevusi: kui lapse kõnes leidus rohkesti verbe, kasutas ta ka rohkesti adverbe; substantiivide ja adjektiivide kasutussageduse vahel nii otsest seost ei ilmnenud.

Koolieelikute sõnavara ning sõnaliigiline jaotumus ja sõnade kasutussagedus on kõrgharidusega emade peredes seotud tugevalt vanema kõnega. Lapsele suunatud kõne annab lapsele ette selle, kui rikas või vastupidi, kui piiratud on sõnavara ühe sõnaliigi sees. Nii emade kui ka laste kõnes 
on kõige rikkam sõnavara substantiivide puhul, peaaegu võrdselt rikas on ka verbi- ja adverbisõnavara, mille järgnevad adjektiivid, pronoomenid ja konjunktsioonid. Seejuures on laste sõnavara ka kõikide sõnaliikide puhul mõnevõrra tihedam, kuna väiksemasse kõne hulka on mahutatud rohkem eri lekseeme.

Siinse esmase spontaanse kõne analüüs näitab ilmselt argivestlusele üldiseltki omast sõnaliigilist jaotumust ja sõnavara suurust. Selgitamaks välja, kas kuueaastaste laste kõne on seotud lastele suunatud kõnega, tuleks analüüsida pikema perioodi jooksul tehtud lindistusi. Kuna siinne uurimus on tehtud kõrgharidusega emade ja nende laste argivestluste põhjal, tuleks edasises uurimuses võrrelda, kas ja millised on erinevused ning kui tugev on see seos näiteks erineva haridustasemega vanemate vahel.

\section{Kirjandus}

Argus, Reili 2008. Eesti keele muutemorfoloogia omandamine. Analüütiline ülevaade. (= Tallinna Ülikooli humanitaarteaduste dissertatsioonid 19.) Tallinn: Tallinna Ülikooli kirjastus.

Argus, Reili, Helen Kõrgesaar 2014. Sõnaliigid eesti lapse kõnes ja lapsele suunatud kõnes. - Eesti Rakenduslingvistika Ühingu aastaraamat 10, 37-53. http://dx.doi.org/10.5128/ERYa10.03.

Bates, Elizabeth, Brian MacWhinney 1987. Competition, variation, and language learning. -Mechanisms of Language Acquisition. Ed. Brian MacWhinney. Hillsdale, NJ, US: Lawrence Erlbaum Associates, Inc, 157-193.

Bates jt 1979 = Elizabeth Bates, Laura Benigni, Inge Bretherton, Luigia Camaioni, Virginia Volterra. The Emergence of Symbols. Cognition and Communication in Infancy. Ed. E. A. Hammel. Language, Thought and Culture. New York: Academic Press.

Behrens, Heike 2006. Children-output relationship in first language acquisition. - Language and Gognitive Processes 21, 2-24.

Bornstein, Marc H., Maurice Haynes 1998. Vocabulary competence in early childhood: measurement, latent construct, and predictive validity. - Child Development 69 (3), 654-671.

Bornstein jt $\mathbf{2 0 0 0}=$ H. Marc Bornstein, M. O. Haynes, Kathleen M. Painter, Janice L. Genevro. Child language with mother and with stranger at home and in the laboratory: a methodological study. - Journal of Child Language 27, 407-420.

Bornstein jt $\mathbf{2 0 0 3}$ = Marc H. Bornstein, Chun-Shin Hahn, Joan T. D. Suwalsky, Maurice O. Haynes. Socioeconomic status, parenting, and child 
development: the Hollingshead four-factor index of social status and the socioeconomic index of occupations. - Monographs in Parenting Series. Socioeconomic Status, Parenting, and Child Development. Eds. M. H. Bornstein, R. H. Bradley. Mahwah, NJ: Lawrence Erlbaum Associates Publishers, 29-82

Bruner, Jerome 1981. The social context of language acquisition. - Language \& Communication 1, 155-178. http://dx.doi.org/10.1016/02715309(81)90010-0.

Davis Kean, Pamela 2005. The influence of parent education and family income on child achievement: the indirect role of parental expections and teh home environment. - Journal of Family Psychology 19, 294-304.

DeGarmo jt 1999 = David S. DeGarmo, Marion S. Forgatch, Charles R. Martinez Jr.. Parenting of divorced mothers as a link between social status and boys' academic outcomes: unpacking the effects of socioeconomic status. - Child Development 70, 1231-1245.

Eriksson jt 2012 = Mårten Eriksson, Peter B. Marschik, Tiia Tulviste, Margareta Almgren, Miguel Pérez Pereira, Sonja Wehberg, Ljubica UmekMarjanovič, Frederique Gayraud, Melita Kovacevic, Carlos Gallego. Differences between girls and boys in emerging language skills: evidence from 10 language communities. - British Journal of Developmental Psychology 30, 326-343.

Fenson jt 1994 = Larry Fenson, Philip S. Dale, J. Steven Reznick, Elisabeth Bates, Donna J. Thal, Stephen J. Pethick, Michael Tomasello, Carolyn B. Mervis, Joan Stiles. Variability in early communicative development. Monographs of the Society for Research of Child Development 59 (5), 1-173. http://dx.doi.org/10.2307/1166093.

Gentner, Dedre 1982. Why nouns are learned before verbs. Linguistic relativity versus natural partitioning. - Language Development. Ed. S. A. Kuczaj. 2, Language, Thought and Culture. Hillsdale, NJ: Lawrence Erlbaum, 301-334.

Gentner, Dedre, Lera Boroditsky 2001. Individuation, and early word learning. - Language Acquisition and Conceptual Development. Eds. Melissa Bowerman, Stephen C. Levinson. New York: Cambridge University Press, 215-256.

Glegg, Judy, Jane Ginsborg 2006. Language and social advantage: theory into practice. Chichester, England: John Wiley \& Sons, Ltd.

Hart, Betty, Todd R. Risley 1995. Experience of Young American Children. Baltimore: Paul Brookes Publishing Co.

Hart, Betty, Todd R. Risley 2003. The Early Catastrophe: The 30 Million Word Gap by Age 3. http://www.aft.org//sites/default/files/periodicals/TheEarlyCatastrophe.pdf. 
Hoff, Erika 2010. Context effects on young children's language use: the influence of conversational setting and partner. - First Language 30 (3-4), 461-472.

Hoff jt 2012 = Erika Hoff, Brett Laursen, Kelly Bridges. Measurement and model building in studying the influence of socioeconomic status on child development. - The Cambridge Handbook of Environment in Human Development. Eds. Linda C. Mayes, Michael Lewis. Cambridge University Press, 590-606. http://dx.doi.org/10.1017/CBO9781139016827.033.

Hoffman, Lois Wladis 2003. Methodological issues in studies SES, parenting, and child development. - Monographs in Parenting Series. Socioeconomic Status, Parenting, and Child Development. Eds. M. H. Bornstein, R. H. Bradley. Mahwah, NJ: Lawrence Erlbaum Associates, 125-143.

Kaasik jt 1977 = Ülo Kaasik, Juhan Tuldava, Astrid Viilup, Kuldev Ääremaa. Eesti tänapäeva ilukirjandusproosa autorikõne lekseemide sagedussõnastik. - Töid keelestatistika alalt. II, Keelestatistika. (= Tartu Riikliku Ülikooli toimetised 413.) Tartu, 5-140.

Kütt, Andra 2015. Eesti keelt emakeelena omandavate laste (vanuses 6-7 eluaastat) sõnavara sotsiolingvistiline uurimus. Magistritöö. Tallinn: Tallinna Ülikool.

Leping, Kristjan-Olari 2005. Inimkapitali ja palga seosed Eestis ning nende dünaamika. - Majandusteadus ja haridus Eestis. Toim. Diana Eerma. Tartu: Tartu Ülikool, 15-43.

Li, Hanhong, Alex C. Fang 2011. Word frequency of the CHILDES corpus: another perspective of child language features. - ICAME Journal 35, 95-116.

McLoyd, Vonnie C. 1998. Children in poverty: development, public policy, and practice. - Handbook of Child Psychology. Ed. William Damon. 4, Child Psychology in Practice. 5th ed. Eds. K. Ann Renninger, Irving E. Sigel. New York: Wiley, 135-208.

Redington jt 1998 = Martin Redington, Nick Chater, Steven Finch. Distributional information: a powerful cue for acquiring syntactic categories. - Cognitive Science 22 (4), 425-469. http:// dx.doi.org/10.1016/S03640213(99)80046-9.

Rowe, David C. Joseph L. Rodgers 1997. Poverty and behavior: are environmental measures nature and nurture? - Developmental Review 17 (3), $358-375$.

Sandhofer jt 2000 = Catherine M. Sandhofer, Linda B. Smith, Jun Luo. Counting nouns and verbs in the input: differential frequencies, different kinds on learning. - Journal of Child Language 27 (3), 561-585.

Schults jt 2012 = Astra Schults, Tiia Tulviste, Kenn Konstabel. Early vocabulary and gestures in Estonian children. - Journal of Child Language 39 (3), 664-686. http://dx.doi.org/10.1017/ S0305000911000225. 
Stoll jt 2012 = Sabine Stoll, Benjamin Biskel, Elena Lieven, Goma Banjade, Toya N. Bhatta, Martin Gaenszle, Netra P. Paudyal, Judith Pettigrew, Ichchha Purna Rai, Manoj Rai, Novel Kishore Rai. Nouns and verbs in Chintang: children's usage and surrounding adult speech. - Journal of Child Language 39 (2), 284-321. http://dx.doi.org/10.1017/S0305000911000080.

Tizard, Barbara, Martin Hughes 1984. Young Children Learning. Harvard University Press.

Tomasello, Michael 1992. First Verbs: A Case Study of Early Grammatical Development. New York, NY, US: Cambridge University Press. http:// dx.doi.org/10.1017/CBO9780511527678.

Tomasello, Michael 2001a. Perceiving intentions and learning words in the second year life. - Language Acquisition and Conceptual Development. Eds. Melissa Bowerman, Stephen C. Levinson. Language Culture and Cognition. Cambridge: Cambridge University Press, 132-158. http:// dx.doi.org/10.1017/CBO9780511620669.007.

Tomasello, Michael 2001b. The Cultural Origins of Human Cognition. Cambridge, MA: Harvard University Press.

Tomasello, Michael 2003. Constructing a Language: A Usage-Based Theory of Language Acquisition. Cambridge, MA: Harvard University Press.

Urm, Ada 2012. Individuaalsete erinevuste stabiilsus eesti laste sõnavara arengus. Magistritöö. Tartu: Tartu Ülikool.

Urm, Ada, Tiia Tulviste 2016. Sources of individual variation in Estonian toddlers' expressive vocabulary. - First Language 36 (6), 580-600. http:// dx.doi.org/10.1177/0142723716673951.

Vihman, Marilyn May, Maigi Vija 2006. The acquisition of verbal inflection in Estonian. - The Acquisition of Verbs and their Grammar: The Effect of Particular Languages. Eds. Natalia Gagarina, Insa Gülzow. (= Studies in Theoretical Psycholingistics 33.) Dordrecht: Springer, 263-295.

Viks, Ülle, Indrek Hein 2001. Sõnavormide kasutus seadusetekstides. Tallinn: Eesti Keele Instituut. http://www.eki.ee/teemad/seadused_kategooriad/ kategooriad.pdf (04.02.2018).

Waxman jt 2013 = Sandra Waxman, Xiaolan Fu, Sudha Arunachalam, Erin Leddon, Katleen Geraghty, Hyun-joo Song. Are nouns learned before verbs? Infants provide insight into a longstanding debate. - Child Development Perspectives 7 (3), 155-159.

Willms, Douglas J. 2003. Ten Hypotheses about Socioeconomic Gradients and Community Differences in Children's Developmental Outcomes. Applied Research Branch, Strategic Policy, Human Resources Development Canada, Final Report. 


\title{
Vocabulary of 6-year-old Estonian-speaking children and their mothers
}

\author{
ANDRA KÜTT, REILI ARGUS
}

Studies on the acquisition of vocabulary of preschoolers and the relationships between social environment and child vocabulary are relatively scarce in Estonia. The goal of the article is to describe, on the basis of recorded everyday conversations (six hours of recorded material in total), the vocabulary and the use of word classes in six-year-old Estonian-speaking children and to demonstrate how the vocabulary of a child depends on the vocabulary of the parent. This study is the first attempt to describe the vocabulary of Estonian children belonging to a specific target group (the children's mothers have all higher education). The results indicate that the vocabulary, distribution of word classes and frequency of words of a specific word class of six-year-old children are closely related to the language use of the parent. The vocabulary of children consisted of about 415-498 lexemes within a recording, whereas the mothers interacting with their children used 557-798 lexemes during the same time span. Like their parents', the preschoolers' vocabulary is in general verb-or adverb-based. Although the parents used somewhat more verbs than their children, child-directed speech proovides children with a general distribution of word classes and the frequency of words inside a specific word class, that is, children's distribution of word classes are similar to their parents'. Both the parents and the children used very few adjectives, whereas there are even less adjectives in the parents' than in the children's speech. The amount of parent speech (measured in tokens) in the recording was $47 \%$ greater than the amount of child speech.

Keywords: first language acquisition, sociolinguistics, word classes, childdirected speech, vocabulary, Estonian 
Andra Kütt

humanitaarteaduste instituut

Tallinna Ülikool

Narva mnt 25

10120 Tallinn

andrakig@tlu.ee

Reili Argus

humanitaarteaduste instituut

Tallinna Ülikool

Narva mnt 25

10120 Tallinn

reili.argus@tlu.ee 